ISSN $1978-3000$

\title{
Korelasi Berat Badan Ayam Leher Gundul (Legund) umur DOC, 4, 8 dan 12 Minggu
}

\author{
The Correlation of Naked Neck Chicken (legund) Body Weight \\ in the Age of 0, 4, 8 and 12 Week \\ Johan Setianto, Warnoto dan Ardanri \\ Jurusan Peternakan, Fakultas Pertanian, Universitas Bengkulu, Bengkulu \\ Jalan Raya Kandang Limun, Bengkulu. Telp. (0736) 21170 pst.219.
}

\begin{abstract}
The research was conducted to study the correlation of naked-neck chicken (legund) body weight in the age of DOC, 4,8 and 12 weeks. A total of 58 naked-neck chicken were used. The chicken were reared in the brooding house for 4 weeks. In the age of 4 weeks until 12 weeks the chicken were reared in the battery cage. In the age of 0 until 4 weeks, they were given feed with Br1. From the age of 4 weeks until 12 weeks the chicken were given feed with mixed feed that was self-mixed with the composition of $37 \%$ of corn, $30 \%$ of mixture of rice and bran, $30 \%$ of concentrate, and $3 \%$ oil. Feed were provided ad libititum and the birds had free access to water. Parameters of the research were the weight of egg, weight of hatch ( 0 weeks/DOC), body weight in the age of 4,8 and 12 weeks. The experimental result showed that the high correlation of body weight was found in the age of 4 weeks with the body weight in the age of 8 and 12 weeks, and the body weight of 8 weeks with the body weight of 12 weeks.
\end{abstract}

Key words : naked-neck, Na gene, egg weight, doc weight, and body weight

\begin{abstract}
ABSTRAK
Penelitian ini bertujuan untuk mengetahui korelasi berat badan ayam legund umur DOC, 4, 8 dan 12 minggu. Materi yang digunakan adalah anak ayam legund sejumlah 58 ekor. Setelah menetas anak ayam legund dipelihara di dalam kandang indukan selama 4 minggu, kemudian dari umur 4 minggu sampai dengan umur 12 minggu ayam dipelihara di dalam kandang baterai. Pada umur 0 sampai 4 minggu anak ayam diberi pakan Br1. Mulai umur 4 minggu sampai 12 minggu, ayam diberi pakan campuran yang dicampur sendiri dengan perbandingan 37\% jagung, 30\% dedak, 30\% konsentrat dan 3\% minyak. Pakan dan air minum diberikan secara ad libitum. Parameter yang diukur adalah berat telur, berat berat tetas ( 0 minggu/DOC), berat badan umur 4, 8 dan 12 minggu. Hasil penelitian menunjukkan bahwa korelasi tinggi didapatkan antara berat badan umur 4 minggu dengan berat badan umur 8 dan 12 minggu, dan umur berat badan 8 minggu dengan berat badan umur 12 minggu.
\end{abstract}

Kata kunci : legund, gen $\mathrm{Na}$, berat telur, berat doc, dan berat badan

\section{PENDAHULUAN}

Ayam leher gundul (legund) merupakan salah satu jenis ternak unggas yang berpotensi cukup tinggi sebagai penghasil daging dan telur, sehingga dapat membantu peningkatan pendapatan dan pemenuhan kebutuhan protein hewani masyarakat. Ayam legund merupakan salah satu keragaman fenotipe ayam lokal, yang ditandai dengan tidak tumbuhnya bulu pada bagian leher, sehingga disebut ayam legund (Warnoto, 1993).

Penampilan leher gundul (legund) pada ayam kampung disebabkan oleh gen $\mathrm{Na}$. 
Sidadolog (1991) menyatakan bahwa dalam keadaan homosigot $(\mathrm{NaNa})$ dapat ditandai dengan adanya perluasan bagian tubuh yang tidak tumbuh bulu (gundul) sampai dada, paha dan sekitarnya. Lebih lanjut dinyatakan dalam keadaan heterosigot (Nana) bagian tubuh yang gundul hanya pada bagian leher saja. Pendapat lain mengemukakan bahwa bagian tubuh yang tidak tumbuh bulu pada keadaan heterosigot (Nana) sebesar $20-30 \%$ dan pada keadaan homosigot $(\mathrm{NaNa})$ sebesar $40 \%$ dari permukaan tubuh yang ditumbuhi bulu dalam keadaan normal ( Mazzi, dkk. 2003).

Ayam legund cukup banyak tersebar di daerah perdesaan sebagai ayam peliharaan oleh masyarakat. Pada kondisi pemeliharaan di perdesaan, ayam legund mempunyai performa produksi telur dan daging yang lebih baik dan lebih tahan terhadap penyakit dibandingkan ayam lokal yang berbulu normal (Barua, dkk.1999). Pendapat lain yang hampir sama menyatakan bahwa ayam legund lebih unggul dalam ketahanan terhadap penyakit dibanding ayam lokal berbulu normal (Islam, 2006).

Gen Na pada ayam legund jantan dan betina secara tidak langsung mempengaruhi pertumbuhan yang lebih baik dibanding ayam kampung berbulu normal mulai umur 6 minggu dan mempunyai kemampuan menggunakan pakan lebih efisien dibanding ayam kampung berbulu normal (Warnoto, 1993). Sementara itu beberapa peneliti melaporkan bahwa ayam legund mempunyai pertumbuhan yang lebih baik daripada ayam berbulu normal pada lingkungan pemeliharaan yang mempunyai temperatur tinggi ( Horst dan Mathur, 1989; Cahaner, dkk., 1993).

Pendugaan nilai korelasi mempunyai arti penting dalam seleksi lebih awal, karena dengan seleksi lebih awal dapat menekan biaya, tenaga dan waktu terutama bagi peternak. Pendugaan nilai korelasi berat badan dengan berat badan yang lebih awal dapat dijadikan acuan untuk peternak. Ayam yang dipelihara untuk tujuan menghasilkan daging, pendugaan nilai korelasi yang mempunyai arti penting adalah hubungan antara berat badan pada umur lebih awal dengan berat badan saat siap potong ( Brandsch, 1981).

Penelitian ini bertujuan untuk mengetahui korelasi berat badan ayam legund umur $0,4,8$ dan 12 minggu.

\section{MATERI DAN METODE}

Penelitian dilaksanakan di Kandang Komersial zone Jurusan Peternakan. Kandang dilengkapi tempat pakan dan tempat air minum. Sebelum digunakan kandang dibebashamakan.

Pengumpulan telur dilakukan setiap hari dari telur yang dihasilkan tetua ayam legund. Telur kemudian ditimbang dan ditetaskan menggunakan mesin tetas. Setelah menetas anak ayam leher gundul ( legund) dipelihara di dalam kandang indukan selama 4 minggu, kemudian dari umur 4 minggu sampai dengan umur 12 minggu ayam dipindah dan dipelihara di dalam kandang baterai. Pada umur 0 sampai 4 minggu anak ayam diberi pakan Br1. Kemudian mulai umur 4 minggu sampai 12 minggu, ayam diberi pakan campuran yang dicampur sendiri dengan perbandingan 37\% jagung, 30\% dedak, 30\% konsentrat dan 3\% minyak. Pakan dan air minum diberikan secara ad libitum.

Parameter yang diukur adalah berat telur, berat berat tetas ( $0 \mathrm{minggu} / \mathrm{DOC})$, berat badan umur 4, 8 dan 12 minggu.

Data berat telur, berat berat tetas (0 minggu/DOC), berat badan umur 4, 8 dan 12 minggu digunakan untuk menghitung korelasi antara data tersebut dengan menggunakan rumus koefisien korelasi sebagi berikut (Warwick, dkk., 1990 ) :

$$
\mathrm{r}=\frac{\sum X Y}{\sqrt{\left(\sum X^{2}\right)\left(\sum Y^{2}\right)}}
$$

Keterangan:

$r$ : koefisien korelasi,

$X$ : variabel $X$,

$\mathrm{Y}$ : variable $\mathrm{Y}$ 


\section{HASIL DAN PEMBAHASAN}

\section{Korelasi berat telur dengan berat DOC, berat DOC dengan berat badan umur 4, 8 dan 12 minggu.}

Bagaimana hasil korelasi antara berat telur dengan berat DOC, berat DOC dengan berat badan umur 4, 8 dan 12 minggu dapat dilihat pada tabel 1 berikut :
Suparyanto (1983) yang mengatakan bahwa hubungan antara berat telur dengan berat DOC dipengaruhi oleh komponen yang ada di dalam telur, yaitu besar atau kecilnya kuning telur. Hasil penelitian lain yang dilakukan Ediyanto dan Husmaini (1992) menunjukkan bahwa berat telur berpengaruh nyata terhadap berat DOC yang dihasilkan.

Hasil yang berbeda ditunjukkan oleh korelasi antara berat DOC dengan berat badan umur 4, 8 dan 12 minggu. Dari sini dapat dilihat bahwa korelasi antara berat DOC

Tabel 1. Korelasi antara berat telur dengan berat DOC, berat DOC dengan berat badan umur 4, 8 dan 12 minggu

\begin{tabular}{lc}
\hline \multicolumn{1}{c}{ Variabel } & Koefisien korelasi ( r) \\
\hline Berat telur dengan berat DOC & 0,76 \\
Berat DOC dengan berat badan 4 minggu & 0,14 \\
Berat DOC dengan berat badan 8 minggu & 0,11 \\
Berat DOC dengan berat badan 12 minggu & 0,11 \\
\hline
\end{tabular}

Dari tabel 1 dapat dilihat bahwa koefisien korelasi antara berat telur dengan berat DOC sebesar $\mathrm{r}=0,76$. Ini berarti bahwa keduanya mempunyai hubungan yang tinggi. Ini dapat juga diterjemahkan bahwa semakin berat telur yang ditetaskan, akan menghasilkan berat DOC semakin berat. Fakta ini tidak dapat dipungkiri. Banyak hasil penelitian melaporkan bahwa berat DOC mempunyai korelasi yang cukup tinggi dengan berat telur. Semakin berat telur yang ditetaskan, maka akan menghasilkan berat DOC yang semakin berat. Ini disebabkan oleh jumlah cadangan makanan embrio yang tersedia dalam telur selama penetasan lebih banyak. Dengan besarnya berat telur berarti semakin banyak cadangan makanan untuk perkembangan embrio. Hubungan antara berat telur dengan berat DOC dipengaruhi oleh komponen-komponen yang ada di dalam telur, yaitu antara lain, besar kecilnya kuning telur. Pendapat ini sesuai dengan pendapat dengan berat badan umur 4, 8 dan 12 minggu menunjukkan hubungan yang lemah. Nilai koefisien korelasinya rendah. Koefisien korelasi antara berat DOC dengan berat badan umur 4 minggu sebasar $\mathrm{r}=0,14$, kemudian $\mathrm{r}=0,11$ dengan berat badan umur 8 minggu dan $r=$ 0,11 dengan berat badan umur 12 minggu. Nilai koefisien korelasi 0,11 - 0,14 ketiganya dikatagorikan rendah. Menurut Sudjana (1996) bahwa angka koefisien korelasi dinyatakan rendah antara 0,05 - 0,25. Dengan demikian nampak bahwa berat badan umur 4,8 dan 12 minggu tidak dipengaruhi oleh berat DOC.

\section{Korelasi antara berat badan umur 4, 8 dan 12 minggu}

Hubungan antara berat badan umur 4 minggu dengan berat badan umur 8 minggu, berat badan umur 4 minggu dengan berat badan 12 minggu maupun antara berat badan umur 8 minggu dengan berat badan umur 12

Tabel 2. Korelasi antara berat bad an umur 4, 8 dan 12 minggu

\begin{tabular}{lc}
\hline \multicolumn{1}{c}{ Variabel } & Koefisien korelasi ( $\mathrm{r}$ ) \\
\hline Berat badan 4 minggu dengan berat badan 8 minggu & 0,71 \\
Berat badan 4 minggu dengan berat badan 12 minggu & 0,71 \\
Berat badan 8 minggu dengan berat badan 12 minggu & 0,83 \\
\hline
\end{tabular}


ISSN $1978-3000$

minggu dapat dilihat pada tabel 2 berikut ini:

Dari tabel 2 nampak bahwa hubungan antara berat badan umur 4 minggu dengan berat badan umur 8 minggu menunjukkan hubungan yang tinggi $(\mathrm{r}=0,71)$. Hubungan yang tinggi juga diperoleh dari hasil antara berat badan umur 4 minggu dengan berat badan umur 12 minggu ( $r=0,71)$ dan antara berat badan umur 8 minggu dengan berat badan umur 12 minggu $(r=83)$. Dengan tingginya nilai koefisien korelasi tersebut di atas, maka dapat diartikan bahwa berat badan umur 4 minggu dapat berpengaruh terhadap berat badan umur 8 dan berat badan umur 12 minggu. Semakin besar berat badan umur 4 minggu, semakin besar berat badan umur 8 dan berat badan umur 12 minggu. Dari hasil ini yang menarik adalah hubungan antara berat badan umur 8 minggu dengan berat badan umur 12 minggu justru menunjukkan nilai koefisien korelasi tertinggi. Nilai korelasi koefisien ini menjdai penting untuk melakukan seleksi agar dapat mencapai hasil yang diinginkan pada masa akhir produksi. Brandsch ( 1981) mengtakan bahwa untuk ayam pedaging, nilai koefisien korelasi yang terpenting adalah hubungan antara berat badan pada umur lebih awal dengan berat badan saat siap potong. Berdasarkan pendapat tersebut dan dari hasil penghitungan koefisien korelasi, maka untuk mendapatkan berat badan yang baik pada umur 8 dan 12 minggu dapat diseleksi berdasarkan berat badan pada saat umur 4 minggu. Selanjutnya untuk mendapatkan berat badan yang baik pada umur 12 minggu, seleksi dapat dilakukan pada berat badan umur 8 minggu. Ini karena nilai koefisien korelasinya yang tertinggi.

\section{SIMPULAN}

bahwa :

Dari hasil penelitian dapat disimpulkan

1. Korelasi yang tinggi diperoleh antara berat telur dengan berat DOC, antara berat badan umur 4 minggu dengan berat badan umur 8 minggu dan berat badan umur 12 minggu, dan antara berat badan umur 8 minggu dengan berat badan umur 12 minggu.

2. Seleksi pada ayam legund sebaiknya dilakukan pada umur 4 dan 8 minggu untuk memperoleh hasil yang baik pada ayam umur 12 minggu.

\section{DAFTAR PUSTAKA}

Barua, A., M.A.R. Howlider and Y. Yoshimura. 1999. Indogenous Naked neck fowl of Bangladesh. World's Poultry Science, 54:279-286.

Brandsch. 1981. Gefluegelzucht. 2nd ed., VEB Deutscher Landwirtschaftsverlag. Berlin.

Cahaner, A., N. Deeb, and M. Gutman, 1993. Effects of the plumage-reducing naked neck $(\mathrm{Na})$ gene on the performance of fastgrowing broilers at normal and high ambient temperatures. Poultry Sci. 72 :767775.

Ediyanto, H. dan Husmaini. 1992. Pengaruh antara bobot telur tetas dengan bobot tetas dan harapan hidup ternak itik local periode awal. Majalah Ilmiah Universitas Jambi.

Horst, P. and P. K. Mathur, 1989. Position of Local fowl for tropical oriented breeding activities. In : MERAT, P. (Ed.). Genotype x Environment Interaction in Poultry. Jouyen-Josas:INRA, p.161-174.

Islam, M. A. (2006) Comperative egg production and egg quality of indigenous full feathered and naked neck chicken at hot-humid climate. Bangladesh Journal of Animal Science 35: 99-105.

Mazzi, C. M., J. F. Apareccido, M. I. F. Tiraboschi, V. J. M. Savino, A. A. D. Coelho and M. Macari. 2003. Polymorphism analysis of the hsp70 stress gene in broiler chickens (Gallus gallus) of different breeds. Genetics and Molecular Biology, 26,3, 275 281.

Sidadolog, J. H. P. 1991. Pengaruh gen Na (Naked Neck) terhadap Pertumbuhan Ayam Kampung. Laporan Penelitian Fakultas Peternakan, Universitas Gadjah Mada, Yogyakarta.

Sudjana. 1996. Metoda Statistika. Cetakan ke VI. Tarsito. Bandung.

Suparyanto, A. 1983. Pengaruh bobot telur terhadap pertumbuhan ayam. Poultry Indonesia. 38 :12 -13.

Warnoto. 1993. Pengaruh gen $\mathrm{Na}$ (legund) terhadap Produksi dan Kualitas Daging Ayam Kampung. Program Pascasarjana Universitas Gadjah Mada. Yogyakarta. (tidak dipublikasikan).

Warwick, E.J., M. Astuti dan W. Hardjosubroto. 1990. Pemuliaan Ternak. Gadjah Mada Press. Yogyakarta. 